\title{
WYDAJNOŚĆ WITRYN INTERNETOWYCH GOSPODARSTW AGROTURYSTYCZNYCH
}

\author{
Karol Król \\ Katedra Gospodarki Przestrzennej i Architektury Krajobrazu Uniwersytetu Rolniczego w Krakowie \\ Kierownik Katedry: prof. dr hab. inż. Krzysztof Gawroński

\begin{abstract}
Słowa kluczowe: promocja agroturystyki, testy wydajności, efektywność witryny, optymalizacja witryny

Key words: promotion of agrotourism, performance tests, efficiency of website, optimization of website

S y n o p s i s. Dynamika rozwoju agroturystyki zależy w dużym stopniu od działań marketingowych, w tym promocji usług. Wielu właścicieli gospodarstw agroturystycznych wykorzystuje witryny internetowe do prezentacji swojej oferty i dotarcia z nią do szerszego grona odbiorców. Takie atrybuty witryny jak: użyteczność, funkcjonalność, interaktywność i wydajność są często postrzegane jako obietnica wysokiej jakości oferty, z której klient rozważa skorzystać. Celem pracy był pomiar wydajności witryn internetowych gospodarstw agroturystycznych. Badania miały charakter pilotażowy i zostały wykonane w zbiorze 100 witryn internetowych, których adresy pozyskano w wyszukiwarki Google oraz jednego z ogólnopolskich katalogów. Testy wydajności wykonano za pomocą wybranych aplikacji internetowych. Ponadto wytypowano strony o skrajnych parametrach, które poddano szczegółowej analizie. W konkluzji wykazano, że witryny internetowe gospodarstw agroturystycznych charakteryzowały się zadowalającym stopniem wydajności, co nie zawsze jednak korespondowało z ich efektywnością i jakością wykonania.
\end{abstract}

\section{WSTĘP}

Turystyka jest zjawiskiem interdyscyplinarnym, jednocześnie ekonomicznym, społecznym i przestrzennym. Z kolei produkt turystyczny to kategoria złożona, obejmująca zarówno elementy usługowe, jak i dobra materialne [Balińska 2014, Kachniewska 2011]. Do głównych elementów produktu turystycznego zaliczyć można walory turystyczne - specyficzne cechy i elementy środowiska przyrodniczego oraz przejawy działalności człowieka, które stanowią przedmiot zainteresowania turysty [Gołembski 2002], a także infrastrukturę turystyczną i usługi turystyczne, choć za jego najważniejszy element przyjmuje się najczęściej walory przyrodnicze [Balińska 2009].

Szczególnym rodzajem turystyki jest agroturystyka, rozumiana jako forma wypoczynku odbywającego się na terenach wiejskich o charakterze rolniczym, oparta na bazie noclegowej i aktywnościach rekreacyjnych związanych z gospodarstwem rolnym lub równoważnym i jego otoczeniem [Drzewiecki 2001]. Duża konkurencja na rynku usług agroturystycznych sprawia jednak, że gospodarstwa agroturystyczne proponują różne rodzaje wypoczynku i szeroki zakres usług [Balińska 2006]. 
Agroturystyka jest jedną z wielu form turystyki rozwijających się na terenach wiejskich, która wyewoluowała z turystyki wiejskiej [Sroka, Wojewodzic 2010, Wojciechowska 2010]. Stanowi istotny kierunek rozwoju obszarów wiejskich jako terenów zagrożonych marginalizacją i jej następstwami. Umożliwia uzyskanie dodatkowych dochodów, co wpływa na poprawę sytuacji finansowej mieszkańców wsi [Król 2016a]. Jest jedną z najpopularniejszych pozarolniczych form działalności gospodarczej prowadzonej na wsi, jednak w większości przypadków stanowi uzupełnienie podstawowej działalności rolniczej. W 2010 roku w Polsce było 10688 gospodarstw rolnych świadczących usługi agroturystyczne, traktowane jako dodatkowy rodzaj działalności, z tego 53\% to indywidualne gospodarstwa rolne o powierzchni użytków rolnych wielkości 1 ha [Matlegiewicz 2015]. Agroturystyka stanowi ważny czynnik ożywienia gospodarczego obszarów wiejskich oraz pobudza rozwój społeczny - dzięki agroturystyce coraz częściej obserwuje się poprawe jakości życia ludności wiejskiej, rozwój infrastruktury wsi oraz podnoszenie kwalifikacji osób zatrudnionych $w$ gospodarstwach [Tyran 2010, s. 203]. Działalność ta daje możliwość alternatywnego wykorzystania wolnych zasobów gospodarstwa rolnego oraz potencjału otoczenia przyrodniczego i kulturowego [Uglis, Jęczmyk 2009]. Prowadzona jest przez osoby w różnym wieku, o różnym wykształceniu, choć badania pokazują, że jest domeną kobiet [Zawadka 2014]. W agroturystyce ważną częścią usługi są korzyści niematerialne turystów, które nie stanowią żadnego kosztu albo nie są brane pod uwagę przez świadczących usługi, co pozostaje nie bez wpływu na ich konkurencyjność cenową [Sirko, Bek 2006]. Rosnące zainteresowanie agroturystyką wśród gospodarstw rolnych jest wynikiem przede wszystkim uwarunkowań ekonomicznych, ale także organizacyjno-prawnych, społecznych, ekologicznych i krajobrazowych [Sikora 2012].

Celem pracy był pomiar wydajności witryn internetowych gospodarstw agroturystycznych oraz próba odpowiedzi na pytania: jakie informacje można uzyskać na podstawie syntetycznego pomiaru wydajności witryny oraz w jakim stopniu jej wydajność przekłada się na efektywność (punkt widzenia właściciela witryny) i użyteczność (punkt widzenia użytkownika), a także jaki wpływ może mieć wydajność na konwersję celu. Badania poprzedziło postawienie hipotezy, że witryny internetowe gospodarstw agroturystycznych charakteryzują się zadowalającą wydajnością, jednak nie koresponduje to z ich efektywnością i jakością wykonania - wydajność witryny nie jest więc parametrem, który przesądza o jej jakości.

\section{INFOTECHNOLOGIE W PROMOCJI AGROTURYSTYKI}

Ostatnie lata przyniosły dynamiczny rozwój infotechnologii, co wywołało przemiany kulturowe oraz cywilizacyjne. Młode pokolenie traktuje Internet jako element rzeczywistości. Różnego rodzaju urządzenia multimedialne stały się narzędziem zabawy, nauki i pracy [Morbitzer 2012]. Za pomocą aplikacji internetowych można wykonać coraz więcej czynności, a aktywność w Internecie zyskuje nowych zwolenników [Suchacka 2010]. Internet stał się przestrzenią, gdzie swoją aktywność podejmuje coraz więcej podmiotów gospodarczych. Jednocześnie postępuje rewolucja ,nieograniczonego przetwarzania danych" (ang. infinite computing), będąca wynikiem trzech trendów: wykładniczego wzrostu mocy obliczeniowych komputerów, szerokiego dostępu do nich i znacznego spadku ich ceny, której najistotniejsze składowe to: wszechobecny, szerokopasmowy Internet i nieograniczone przetwarzanie wielkich zbiorów danych o zachowaniu obiektów w czasie realnym [Płoszajski 2013, s. 5]. 
Zastosowanie nowoczesnych rozwiązań biznesu elektronicznego stało się jednym z kluczowych aspektów funkcjonowania branży turystycznej. Technologie informacyjno-komunikacyjne (ang. information and communication technologies, ICT) kształtują jej rozwój. Niedogodności związane z fizycznym oddaleniem miejsca zakupu i konsumpcji turystycznej są skutecznie niwelowane przez multimedialne i skomputeryzowane narzędzia marketingowe, które pozwalają coraz sugestywniej kreować wyobrażenia o konkretnych usługach turystycznych [Kachniewska 2011, s. 239].

Działalność agroturystyczna realizowana w otoczeniu konkurencyjnym powinna uwzględniać takie działania, które pozwolą gospodarstwom pozyskać satysfakcjonującą liczbę klientów [Wilk, Keck-Wilk 2013]. Po stworzeniu produktu agroturystycznego i ustaleniu ceny, informacja o tym powinna być przekazana potencjalnym klientom. Konkurencyjność agroturystyki mogą podnieść innowacyjne rozwiązania wprowadzane w obszarze działań marketingowych [Sikorska-Wolak, Zawadka 2016]. Wielu właścicieli gospodarstw agroturystycznych poszukuje więc sposobów wyróżnienia swojej oferty i dotarcia z nią do szerszego grona odbiorców [Krzyżanowska 2014, Król 2016b]. Najczęściej wykorzystują do tego potencjał witryn internetowych, które pozwalają budować wizerunek i markę, a także kreować wyobrażenia o świadczonych usługach. Interaktywność, funkcjonalność i użyteczność witryn może wpływać na decyzje zakupowe, w tym na skłonność do zakupów [Herrero, San Martín 2012]. Posiadanie strony internetowej nie gwarantuje jednak sukcesu. Witryna powinna być przygotowana według standardów projektowych, z uwzględnieniem aktualnych trendów i osiągnięć technologicznych, a o jej sukcesie decyduje wiele czynników. Jednym z nich jest wydajność.

\section{PROBLEMATYKA WYDAJNOŚCI WITRYN INTERNETOWYCH}

Przeglądanie witryn internetowych dotarło do krytycznego punktu. W ciągu ostatniej dekady zwiększyły one swoją objętość ponaddziesięciokrotnie [Zhu, Reddi 2013]. Coraz bardziej rozbudowane, multimedialne i interaktywne witryny są wynikiem rozwoju technologicznego i oczekiwań użytkowników, którzy nie są zainteresowani infrastrukturą, za pomocą której dostarczane są treści, jedynie efektywnością ich przeglądania, modyfikacji i pobierania [Zatwarnicka, Zatwarnicki 2011]. Ponadto wymagają oni funkcjonalności i użyteczności wszystko to powinno być dostępne w sposób natychmiastowy i dynamiczny [Dickinger, Stangl 2013]. Generuje to zapotrzebowanie na systemy komputerowe i urządzenia mobilne o wysokiej wydajności, które zapewnią komfort przeglądania witryn dostarczających coraz bardziej złożonych funkcjonalności [Barczak, Zacharczuk 2014, Ochim, Pańczyk 2016].

$\mathrm{Z}$ punktu widzenia programisty wydajność jest miarą techniczną, inżynierską. Może wynikać z przyjętych rozwiązań projektowych, zastosowanych technik i komponentów. Jest obciążona błędami projektowymi i stanowi parametr diagnozujący ogólną sprawność witryny. Z punktu widzenia użytkownika wydajność jest miarą użyteczności. Stanowi parametr decydujący o komforcie jej przeglądania, co może mieć przełożenie na konwersję celu (efektywność witryny) [Sanders, Galloway 2013]. Ta z kolei leży w sferze zainteresowań właścicieli witryn.

Czas wczytywania witryny w oknie przeglądarki należy do najbardziej podstawowych i niedocenianych parametrów wydajności. Zasadniczo czynniki, które go warunkują, można sprowadzić do niezawodności serwera hostingowego, sprawności łącza internetowego oraz objętości treści i formy ich prezentacji (na czas wczytywania strony mają wpływ m.in. rozmiar pliku HTML, liczba i rozmiar zewnętrznych plików CSS oraz JavaScript, a także 
całkowita wielkość plików graficznych i elementów multimedialnych). Z badań Google wynika, że szybko wczytujące się witryny generują mniejsze koszty utrzymania, są chętniej i dłużej przeglądane, a nawet półsekundowe opóźnienie ma wpływ na statystyki aktywności użytkowników [Singhal, Cutts 2010, Rek, Sulikowski 2011]. Ponadto wydajność strony jest jednym z czynników wpływających na jej miejsce w wynikach wyszukiwania.

\section{MATERIAŁY I METODY}

Ocena efektywności witryn internetowych podmiotów gospodarczych może być pomocna przy identyfikacji newralgicznych punktów, których poprawa (optymalizacja) może wpłynąć na skuteczność działań marketingowych [Plaza 2011]. Zaliczyć do nich można m.in.: technikę wykonania witryn [Król 2015a], jakość treści [Platania 2014, Zopounidis i in. 2014], funkcjonalność [Król 2015b], użyteczność, interaktywność i łatwość nawigacji [Herrero, San Martín 2012], a także wydajność [Dickinger, Stangl 2013].

Badania miały charakter pilotażowy, zostały wykonane w sposób nieformalny ${ }^{1}$ i polegały na ocenie wartości wybranych parametrów wydajności witryn za pomocą aplikacji internetowych, które umożliwiły ich pomiar w sposób zautomatyzowany (tab. 1.).

Tabela 1. Aplikacje wykorzystane w badaniach wydajności

\begin{tabular}{ll}
\hline $\begin{array}{l}\text { Aplikacja testująca (adres } \\
\text { internetowy) }\end{array}$ & \multicolumn{1}{c}{ Mierzone (identyfikowane) parametry } \\
\hline $\begin{array}{l}\text { Pingdom Website Speed Test } \\
\text { tools.pingdom.com) }\end{array}$ & $\begin{array}{l}\text { Czas wczytywania witryny w oknie przeglądarki (s); } \\
\text { rozmiar witryny (MB); liczba i rodzaj wykorzystywanych } \\
\text { zasobów; responsywność }\end{array}$ \\
\hline $\begin{array}{l}\text { Google Mobile Website Speed } \\
\text { Testing Tool - MWS (testmysite. } \\
\text { thinkwithgoogle.com) }\end{array}$ & $\begin{array}{l}\text { Ocena algorytmiczna, punktowa, syntetyczna: wygody } \\
\text { korzystania z witryny na urządzeniach mobilnych; } \\
\text { szybkości wczytywania witryny na urządzeniach mobilnych } \\
\text { i komputerach }\end{array}$ \\
\hline $\begin{array}{l}\text { Complex SEO Audit } \\
\text { (seomastering.com) }\end{array}$ & $\begin{array}{l}\text { Identyfikacja systemu zarządzania treścią CMS; } \\
\text { identyfikacja komponentów rozszerzających funkcjonalność } \\
\text { i interaktywność }\end{array}$ \\
\hline
\end{tabular}

Źródło: opracowanie własne.

Pomiary wykonano na zbiorze 100 witryn internetowych gospodarstw agroturystycznych, których adresy pozyskano 24 maja 2017 r. z tzw. wyników organicznych (,naturalnych”), tj. takich, które nie obejmują wyników płatnych (linków sponsorowanych), oraz z katalogu witryn onet.pl. Adresy skompletowano po przeszukaniu 15 kart SERP (ang. Search Engine Results Page) wyszukiwarki Google, dostępnych po wpisaniu słów kluczowych ,agroturystyka Małopolska”. Wyszukiwarkę Google wybrano z uwagi na jej dużą popularność w świecie [Choi, Varian 2012]. Ponadto w zbiorze badanych witryn wytypowano strony o skrajnych parametrach i poddano je szczegółowym badaniom. Objęły one weryfikację wydajności witryn, ich historię (z wykorzystaniem internetowego archiwum witryn - Internet Archive: Wayback Machine) oraz dane udostępniane przez Naukową i Akademicką Sieć Komputerową (NASK), instytut badawczy pełniący funkcję rejestratora domen krajowych.

\footnotetext{
Testy nieformalne umożliwiają relatywnie szybkie i często bezkosztowe pomiary, których wykonanie nie wymaga certyfikowanych laboratoriów.
} 


\section{WYNIKI I WNIOSKI}

W zbiorze badanych witryn odnotowano 46 adresów internetowych w domenie krajowej najwyższego poziomu (domena.pl, ang. ccTLD country code top-level domain), 24 adresy stanowiące subdomenę, tj. adres internetowy, który przynależy do domeny głównej lub domeny wyższego poziomu oraz 8 witryn utrzymywanych (hostowanych) na serwerach bezpłatnych.

Pomiary czasu wczytywania witryny w oknie przeglądarki, rozmiaru jej plików składowych oraz liczby i rodzaju wykorzystywanych zasobów zewnętrznych wykonano za pomocą aplikacji internetowej Pingdom Website Speed Test. Objętość plików 47 witryn, według algorytmu testującego Pingdom, nie przekroczyła $1 \mathrm{MB}$, a w 32 przypadkach mieściła się w przedziale od 1 do $3 \mathrm{MB}$. Objętość 21 witryn przekroczyła $3 \mathrm{MB}$, z czego 3 liczyły kilkanaście MB, a objętość jednej przekroczyła 20 MB. Tak duży rozmiar plików składowych witryny znacząco spowalnia jej wczytanie w oknie przeglądarki internetowej. Większość testowanych witryn wykorzystywała zasoby (w tym pliki graficzne, CSS i JavaScript) nieprzekraczające 2MB, co jest wynikiem relatywnie dobrym. Szczegółowo liczba witryn gospodarstw agroturystycznych ze względu na objętość przedstawiała się następująco: 0,048-0,099 MB - 3, 0,1-0,499 MB - 23, 0,5-0,99 MB - 21, 1,0-1,9 MB $-16,2,0-2,9 \mathrm{MB}-16,3,0-7,9 \mathrm{MB}-17$, powyżej $10 \mathrm{MB}-4$.

W zbiorze badanych witryn odnotowano stosunkowo dużo takich, które według algorytmu Pingdom wczytywane były w oknie przeglądarki ponad 5 sekund, choć najwięcej było takich, które wczytywane były w oknie przeglądarki w czasie od 1 do 3 sekund, co jest wynikiem zadowalającym. W przypadku 5 witryn czas ten wyniósł kilkanaście sekund, co może zniechęcić odbiorcę do przeglądania witryny. Szczegółowo liczba witryn gospodarstw agroturystycznych w podziale na czas oczekiwania na ich wczytanie w oknie przeglądarki internetowej była następująca: 0,5-0,9 s - 9, 1,0-1,9 s - 19, 2,0-2,9 s - 25, 3,0-3,9 s - 17, 4,0-4,9 s - 11, dłużej niż $5 \mathrm{~s}-19$.

Testowane witryny najczęściej odwoływały się do plików graficznych. Łącznie odnotowano 2779 takich plików. Stanowiły one nieco ponad 51\% odwołań, co równało się 79\% objętości wszystkich odnotowanych zasobów. Jest to związane z wizualną oprawą witryn, która jest tworzona przeważnie na podstawie odpowiednio przygotowanych fotografii, uzupełnianych przez różnorakie grafiki.

Podczas testów wykonanych za pomocą aplikacji Complex SEO Audit w zbiorze badanych witryn zidentyfikowano 16 różnych narzędzi wykorzystywanych do budowy funkcjonalności i interaktywności, a także umożliwiających zarządzanie treścią (ang. Content Management System, CMS). Najpopularniejszym była biblioteka jQuery JavaScript, która jest często wykorzystywana do tworzenia dynamicznych prezentacji obrazów. Spośród systemów CMS najpopularniejsze były WordPress oraz Joomla!, odnotowane odpowiednio 16 i 11 razy. Zidentyfikowano także systemy Drupal, QuickCMS i inne. Jedynie w przypadku 14 witryn odnotowano wykorzystanie statystyk internetowych, w tym Google Analytics. Aplikacja Google Analytics dostarcza wiarygodnych informacji o statystykach użytkowania witryny, jej użytkownikach, zasięgu oddziaływania i konwersji celu. Mogą być one pomocne przy optymalizacji i poprawie efektywności witryny.

Wykorzystanie systemów CMS i różnorakich narzędzi zwiększających interaktywność witryny może wpływać na jej wydajność. Badania pokazują, że witryny oparte na CMS mają przeważnie większą objętość niż pozostałe (np. kodowane ręcznie, ang. Hand-Coding Web Pages). Rozmiar 18 witryn, w przypadku których zidentyfikowano CMS, przekraczał $2 \mathrm{MB}$, a w 5 przypadkach mieścił się w przedziale od 1 do $2 \mathrm{MB}$. Ponadto 
w zbiorze badanych witryn odnotowano 34, które wykonano w technologii RWD lub AWD (ang. Responsive Web Design, Adaptive Web Design, dostosowanie witryny do urządzeń mobilnych), z czego według algorytmu Pingdom rozmiar 25 przekroczył 2 MB. W przypadku 5 witryn odnotowano pliki graficzne przekraczające swą objętością $10 \mathrm{MB}$, a w 39 przypadkach odnotowano pliki graficzne o łącznym rozmiarze z przedziału od 1 do $7 \mathrm{MB}$. Witryny te charakteryzowały się także większą liczbą odwołań do plików graficznych, skryptów, multimediów i arkuszy stylów CSS (w przypadku 3 witryn odnotowano ponad 190 odwołań do zasobów zewnętrznych).

Aplikacja Mobile Website Speed Testing Tool (MWS) ocenia witryny internetowe pod względem szybkości wczytywania oraz komfortu ich przeglądania na urządzeniach typu „desktop" oraz mobilnych. W każdej płaszczyźnie testu algorytm aplikacji wylicza notę w skali od 0 do 100 punktów. Im wyższa wartość noty, tym lepsza wydajność lub większy komfort korzystania $\mathrm{z}$ witryny (stymulanty). W trakcie testów wykonywanych za pomocą aplikacji MWS w 86 przypadkach odnotowano większą wydajność witryn na urządzeniach typu „desktop" niż przenośnych. Jedynie 7 witryn było wydajniejszych na urządzeniach mobilnych.

Wartości pomiarów wydajności witryn, pozyskane za pomocą MWS, na urządzeniach typu „desktop” oraz mobilnych porównano używając statystycznego wskaźnika podobieństwa struktur. Jego wartość równa 95,8\% wskazuje na ich duże podobieństwo, co może świadczyć, że zarówno witryny internetowe, jak i urządzenia przenośne są coraz bardziej wydajne. Ponadto wartości tak pozyskanych wskaźników poddano normalizacji z wykorzystaniem metody unitaryzacyjnej celem zastąpienia ich zróżnicowanych zakresów zmienności zakresem stałym i doprowadzenia ich do wzajemnej porównywalności [Walesiak 2014, Śledzik 2014]. Następnie wyznaczono wartości zmiennej zagregowanej uwzględniającej pomiar w trzech płaszczyznach, co pozwoliło pogrupować witryny według stopnia wydajności. Z tak pozyskanych wyników można wnioskować, że ogólna wydajność ocenianych witryn, według pomiaru MWS, jest dostateczna (tab. 2.).

Tabela 2. Liczba witryn według pomiaru wydajności MWS (po znormalizowaniu)

\begin{tabular}{lcccccc}
\hline Wydajność & Błędy testu & Zła & Mierna & Dostateczna & Dobra & Bardzo dobra \\
\hline Skala pomiaru & & $0,01-0,99$ & $1-1,49$ & $1,5-1,99$ & $2,0-2,49$ & $2,5-3,0$ \\
Liczba witryn & 3 & 8 & 19 & 44 & 19 & 7 \\
\hline
\end{tabular}

Źródło: opracowanie własne.

\section{POGŁĘBIONA ANALIZA WYBRANYCH WITRYN}

W zbiorze badanych witryn szczególną uwagę zwróciły witryny ranchoadama. pl (gospodarstwo agroturystyczne Ranczo Adama) oraz agroturystykagwarek.pl (gospodarstwo agroturystyczne Złoty Karpik mieszczące się w miejscowości Gwarek). Pierwsza z uwagi na dużą objętość plików według algorytmu Pingdom (sięgającą aż $20 \mathrm{MB}$ ) oraz dużą liczbę odwołań do zasobów zewnętrznych. Druga zaś z uwagi na mały rozmiar witryny i niewielką liczbę wykorzystywanych zasobów (tab. 3.).

Witryna ranchoadama.pl jest rozbudowana, nowoczesna, multimedialna i przygotowana w technologii RWD (do jej utworzenia wykorzystano Bootstrap - framework CSS, ułatwiający tworzenie interfejsu graficznego stron). Jej wygląd dostosowuje się 
Tabela 3. Wartości wybranych parametrów wydajności oraz technika wykonania witryn internetowych gospodarstw: Ranczo Adama oraz Złoty Karpik

\begin{tabular}{lcccc}
\hline $\begin{array}{l}\text { Witryna } \\
\text { internetowa }\end{array}$ & \multicolumn{2}{c}{ Pingdom: testowane parametry } & Complex SEO Audit \\
\cline { 2 - 5 } & $\begin{array}{c}\text { czas } \\
\text { wczytywania } \\
{[\mathrm{s}]}\end{array}$ & $\begin{array}{c}\text { rozmiar } \\
\text { strony } \\
{[\mathrm{MB}]}\end{array}$ & $\begin{array}{c}\text { liczba } \\
\text { odwołań }\end{array}$ & $\begin{array}{c}\text { technologie } \\
\text { i komponenty }\end{array}$ \\
\hline $\begin{array}{l}\text { ranchoadama.pl } \\
\text { Ranczo Adama }\end{array}$ & 11,13 & 20,3 & 107 & $\begin{array}{c}\text { CompleteCMS, Bootstrap, } \\
\text { jQuery, Google Analytics, } \\
\text { Google Maps, Cookie Script }\end{array}$ \\
\hline $\begin{array}{l}\text { agroturystykagwarek.pl } \\
\text { Złoty Karpik }\end{array}$ & 1,24 & 0,070 & 23 & Brak (pure HTML) \\
\hline
\end{tabular}

Źródło: opracowanie własne z wykorzystaniem Pingdom Website Speed Test oraz Complex SEO Audit.

do ekranu urządzenia, na którym jest przeglądana. Zarządzanie treścią witryny odbywa się za pomocą systemu „CompleteCMS” (zaplecze dostępne po zalogowaniu się). Na jej oprawę graficzną składają się m.in. pliki graficzne i efekty generowane z biblioteki jQuery JavaScript. Witryna jest funkcjonalna - umożliwia rezerwację i płatność za usługi. Te z kolei są zróżnicowane, a sama infrastruktura obiektu rozbudowana. Rancho Adama to całoroczny obiekt z zapleczem gastronomicznym, oferujący organizację różnorakich imprez okolicznościowych, w tym wesel, i firmowych. Z treści udostępnionych na stronie internetowej można wywnioskować, że działalność jest prowadzona przez członków rodziny, a oferta jest skierowana głównie na rynek krajowy (brak przekładu na języki obce). Choć usługodawca powołuje się na walory przyrodnicze okolicy (lasy, łąki i trasy spacerowe), na terenie obiektu utrzymuje mini zoo ze zwierzętami domowymi i gospodarskimi, a także oferuje jazdę konną, trudno się oprzeć wrażeniu, że oferta ma niewiele wspólnego $\mathrm{z}$ tradycyjnie rozumianą agroturystyką. Przypomina bardziej neoagroturystykę [Roman 2013], quasi agroturystykę lub działalność stylizowaną na agroturystykę. Oferta jest próbą połączenia tradycyjnego wypoczynku na obszarach wiejskich z luksusowym obiektem noclegowym, restauracją, basenem i szeregiem atrakcji, takich jak paintball, quady, sauna, basen i jacuzzi, które nie są powszechnie dostępne w gospodarstwach agroturystycznych.

Domenę ranchoadama.pl zarejestrowano w NASK w 2001 r. Analiza cyfrowych archiwów Internetu (Internet Archive: Wayback Machine) pokazała, że od samego początku adres ten firmował działalność jednego podmiotu, co świadczy o jego wiarygodności. Analiza archiwów pokazała również, jak od 2001 r. ewoluowała oferta noclegowa oraz oprawa graficzna witryny - w początkowym okresie gospodarstwo prowadzone było pod szyldem agroturystyki, aby ostatecznie funkcjonować jako ośrodek wypoczynkowy. Kilkukrotna modernizacja witryny oraz rozszerzenie oferty świadczy o rozwoju działalności i zmianie klienta docelowego.

Witryna internetowa Rancza Adama oddaje skalę działalności prowadzonej przez gospodarstwo. Jest wykonana profesjonalnie i zachęca do zapoznania się z ofertą. Wymaga jednak optymalizacji. Testy wykazały, że czas jej wczytania w oknie przeglądarki według algorytmu Pingdom przekracza 10 sekund, a rozmiar plików graficznych prezentowanych na stronie można zmniejszyć o $6 \mathrm{MB}$. Dotyczy to w szczególności obrazów tła, a w zasadzie fotografii, które w niektórych przypadkach są rozmiaru nawet $4256 \mathrm{px} \times 2832 \mathrm{px}$. Rozmiar plików graficznych oraz duża liczba odwołań do zasobów zewnętrznych sprawiają, 
że witryna może być wczytywana relatywnie długo, zarówno na urządzeniach mobilnych, jak i komputerach. Oddają to wyniki testów Mobile Website Speed Testing Tool (tab. 4.), według których witrynę charakteryzuje wygoda przeglądania na urządzeniach mobilnych (w kontekście wielkości elementów nawigacji i układu menu), ograniczana jednak przez powolne wczytywanie poszczególnych obiektów w oknie przeglądarki (zaledwie 4 punkty na 100 możliwych w teście wydajności).

Tabela 4. Objętość, liczba zasobów i wydajność witryn Ranczo Adama oraz Złoty Karpik

\begin{tabular}{lcccccccc}
\hline Witryna internetowa & \multicolumn{3}{c}{$\begin{array}{c}\text { Pingdom: objętość i liczba zasobów } \\
\text { zewnętrznych według typu }\end{array}$} & \multicolumn{3}{c}{$\begin{array}{c}\text { Mobile Website Speed: } \\
\text { wydajność witryn }\end{array}$} \\
\cline { 2 - 9 } & $\begin{array}{c}\text { Image } \\
\text { (MB) }\end{array}$ & $\begin{array}{c}\text { Script } \\
\text { (KB) }\end{array}$ & $\begin{array}{c}\text { Other } \\
\text { (KB) }\end{array}$ & $\begin{array}{c}\text { HTML } \\
\text { (KB) }\end{array}$ & $\begin{array}{c}\text { CSS } \\
\text { (KB) }\end{array}$ & $\begin{array}{c}\text { Mobile } \\
\text { wygoda }\end{array}$ & $\begin{array}{c}\text { Mobile } \\
\text { szybkość }\end{array}$ & $\begin{array}{c}\text { Desktop } \\
\text { szybkość }\end{array}$ \\
\hline ranchoadama.pl & 19,38 & 739,98 & 115,82 & 48,93 & 48,80 & & & 4 \\
Ranczo Adama & 54 & 26 & 11 & 4 & 3 & 99 & 4 & 4 \\
\hline agroturystykagwarek.pl & 0,068 & 0 & 0 & 1,24 & 0,05 & & & \\
Złoty Karpik & 21 & 0 & 0 & 1 & 1 & 89 & 91 & 97 \\
\hline
\end{tabular}

Źródło: opracowanie własne z wykorzystaniem Pingdom Website Speed Test oraz Mobile Website Speed Testing Tool.

Przeciwieństwem witryny ranchoadama.pl jest witryna agroturystykagwarek.pl. Jest to prosta, statyczna wizytówka, prezentująca ofertę gospodarstwa agroturystyczno-rybackiego Złoty Karpik. Domena została zarejestrowana w NASK w 2011 r., jednak technika jej wykonania, a także sposób zapisu kodu i błędy składniowe mogłyby sugerować, że powstała ona w latach 2000-2004. Jest to witryna wykonana w archaiczny sposób i prezentująca jedynie podstawowe informacje o działalności gospodarstwa. Kopie witryny zarchiwizowane przez Wayback Machine wskazują, że jej szata graficzna pozostaje od 2011 r. niezmieniona. Skromna oprawa graficzna, statyczny charakter, brak multimediów i funkcjonalności sprawiają, że witryna wczytywana jest w oknie przeglądarki szybko. Nie rekompensuje to jednak faktu, że nie spełnia obowiązujących standardów projektowych.

\section{PODSUMOWANIE}

Witryny i aplikacje internetowe stają się coraz bardziej przydatne i wyrafinowane multimedialne, funkcjonalne i użyteczne. W przeciwieństwie do swoich komputerowych odpowiedników uruchamiane są bezpośrednio w oknie przeglądarki internetowej i nie wymagają instalacji. Ma to jednak swoje konsekwencje. Ilość danych pobieranych przez urządzenia telekomunikacyjne odbiorców rośnie w stałym tempie. Pomimo tego, że łącza internetowe stają się coraz szybsze, wielu użytkowników nadal wykorzystuje limitowane taryfy, obarczone opłatami za dodatkowy transfer danych - szczególnie w przypadku Internetu mobilnego. Rośnie więc znaczenie optymalizacji wybranych parametrów witryn, która ma zagwarantować ich najwyższą wydajność przy relatywnie najmniejszym obciążeniu łączy.

Optymalizacja witryny jest zjawiskiem złożonym. Polega na zidentyfikowaniu i wyeliminowaniu zbędnych zasobów, tj. takich, które nic nie wnoszą lub wnoszą niewiele, spełniających często jedynie funkcję dodatku (np. prezentacja pogody, sondy internetowe, 
liczniki odwiedzin), wczytywanych z lokalizacji zewnętrznych i wprowadzających swoisty „szum informacyjny” [Król 2016c]. W dalszej kolejności wiąże się z minimalizacją objętości pozostałych elementów witryny poprzez np. kompresję plików graficznych lub minifikację kodu. Przy czym witryny wymagają najczęściej optymalizacji plików graficznych, co jest jednym z najprostszych zabiegów optymalizacyjnych i powoduje zwykle najwyższe wzrosty wydajności. Istotny jest także stały monitoring zasobów i rozważny dobór tych, które są udostępniane ze źródeł zewnętrznych (ich wydajność zwykle zależy jedynie od usługodawcy, ponadto ich awaria może się przyczynić do awarii witryny, na której są udostępniane lub do spadku jej wydajności).

Wyniki badań mogą dać przyczynek stwierdzeniu, że istnieje zależność pomiędzy skalą prowadzonej przez gospodarstwo działalności a jakością witryny internetowej. Gospodarstwa agroturystyczne, które dysponują dużą liczbą miejsc noclegowych i jednocześnie prowadzą małą gastronomię, handel lub świadczą usługi w zakresie organizacji imprez masowych, mają przeważnie profesjonalne i rozbudowane witryny o licznych funkcjonalnościach, natomiast gospodarstwa, dla których agroturystyka jest dodatkową formą zarobkowania, posiadają zwykle witryny wykonywane w sposób amatorski [Król i Bedla 2014]. Ponadto jakość witryny internetowej może świadczyć o tym, do jakich klientów kierowana jest oferta oraz jaką rolę spełnia w ich pozyskiwaniu.

Witryna internetowa jest wizytówką. Jej zła jakość może być odebrana przez użytkownika jako brak zaangażowania i nieumiejętność gospodarzy. O ile niska wydajność ogólnie słabych witryn - ubogich w treści, nieaktualizowanych i nieoferujących żadnych funkcjonalności nie ma większego znaczenia, o tyle w przypadku witryn utworzonych z myślą o przyjmowaniu zapytań ofertowych, rezerwacji noclegów lub umożliwiających płatność bezgotówkową stanowić może poważny mankament. Może on mieć negatywny wpływ na konwersję celu (efektywność witryny) i wywoływać określone zachowania użytkowników, np. zaprzestanie wypełniania formularza rezerwacji z powodu powolnego wczytywania kolejnych stron serwisu.

Witryny internetowe gospodarstw agroturystycznych charakteryzują się zadowalającym stopniem wydajności, co nie zawsze koresponduje z ich efektywnością i jakością wykonania. Wydajność witryny nie jest parametrem, który przesądza o jej jakości. Witryny amatorskie, wykonane w oparciu o archaiczne specyfikacje, z pominięciem standardów projektowych mogą być szybko wczytywane w oknie przeglądarki (choćby z uwagi na niewielki rozmiar grafik i prostotę wykonania), jednak ich ogólna jakość pozostawia często wiele do życzenia.

Trudno analizować wydajność witryny w oderwaniu od ogólnego stopnia jej optymalizacji i jakości w ogóle. Niska wydajność może być symptomem niedoskonałości technicznych lub wynikiem niewłaściwego zarządzania treścią - jest wiele czynników, które mogą spowolnić stronę po upływie pewnego czasu od optymalizacji, np. opublikowanie dużej, nieskompresowanej grafiki. Witryny internetowe gospodarstw agroturystycznych, które są mało wydajne, wykonane w archaiczny sposób i niezoptymalizowane plasowały się na odległych miejscach w wynikach wyszukiwania. Zatem szanse pozyskania klienta za ich pośrednictwem są niewielkie lub żadne. Witryny te nie spełniają swojej funkcji. Można je przyrównać do kwatery, o której istnieniu nikt nie wie, a jeśli już się dowie, to rezygnuje z noclegu z uwagi na mierną, mało wiarygodną prezentację usługi, która może przecież świadczyć o jej złej jakości. Wszystko to sprawia, że opłaty poniesione z tytułu abonamentu domeny i pakietu hostingowego nie zwrócą się, i poddaje w wątpliwość utrzymywanie takiej strony. 


\section{LITERATURA}

Balińska Agata, 2006: Czynniki rozwoju agroturystyki w Polsce. „Roczniki Naukowe Stowarzyszenia Ekonomistów Rolnictwa i Agrobiznesu", nr 8(4), s. 28-32.

Balińska Agata, 2009: Walory turystyczne w tworzeniu i realizacji produktu turystycznego. „Studia i Materiały Centrum Edukacji Przyrodniczo-Leśnej”, nr 11(4 [23]), s. 36-42.

Balińska Agata, 2014: Aktywność turystyczna mieszkańców wsi w kontekście przemian społeczno-gospodarczych - rzeczywisty i potencjalny popyt turystyczny mieszkańców wsi. „Roczniki Naukowe Ekonomii Rolnictwa i Rozwoju Obszarów Wiejskich”, nr 101(2), s. 112-122.

Barczak Andrzej, Dariusz Zacharczuk, 2014: Techniki wpływania na wydajność aplikacji webowych $w$ warstwie prezentacji danych. „Studia Informatica”, nr 35(2), s. 251-267.

Choi Hyunyoung, Hal Varian, 2012: Predicting the present with Google Trends. "Economic Record", no. 88(s1), p. 2-9. doi: 10.1111/j.1475-4932.2012.00809.x.

Dickinger Astrid, Brigitte Stangl, 2013: Website performance and behavioral consequences: A formative measurement approach. „Journal of Business Research”, no. 66(6), p. 771-777. doi: 10.1016/j. jbusres.2011.09.017.

Drzewiecki Maciej, 2001: Podstawy Agroturystyki. OW OPO, Bydgoszcz.

Gołembski Grzegorz (red.), 2002: Kompendium wiedzy o turystyce. PWN, Warszawa.

Herrero Ángel, Héctor San Martín, 2012: Developing and testing a global model to explain the adoption of websites by users in rural tourism accommodations. „International Journal of Hospitality Management", no. 31(4), p. 1178-1186. doi: 10.1016/j.ijhm.2012.02.005.

Kachniewska Magdalena, 2011: Wpływ nowych technologii na rynek ustug pośredników turystycznych. „International Journal of Management and Economics”, nr 32, s. 239-258.

Król Karol, 2015a: Funkcja witryn internetowych gospodarstw agroturystycznych wedlug modelu wdrożenia technologii internetowej SMWTI. „Acta Sci. Pol. Formatio Circumiectus”, nr 14(2), s. 111-123. doi: 10.15576/ASP.FC/2015.14.2.111.

Król Karol, 2015b: Funkcjonalność oraz funkcje witryn internetowych gospodarstw agroturystycznych. „Ekonomia i Zarządzanie”, nr 7(1), s. 343-355. doi: 10.12846/j.em.2015.01.21.

Król Karol, 2016a: Globalne zmiany technologiczne i ich wplyw na promocję agroturystyki w internecie. „Roczniki Naukowe Ekonomii Rolnictwa i Rozwoju Obszarów Wiejskich”, nr 103(3), s. 84-100.

Król Karol, 2016b: Ocena dostępności witryn internetowych małopolskich gospodarstw agroturystycznych dla osób niepetnosprawnych. „Problemy Drobnych Gospodarstw Rolnych - Problems of Small Agricultural Holdings", nr 2, s. 45-61. doi: 10.15576/PDGR/2016.2.45.

Król Karol, 2016c: Audyt dostępności witryn internetowych małopolskich gmin wiejskich. „Roczniki Naukowe Ekonomii Rolnictwa i Rozwoju Obszarów Wiejskich”, nr 103(1), s. 74-85.

Król Karol, Dawid Bedla, 2014: Ocena witryn internetowych gospodarstw agroturystycznych. „Marketing i Rynek", nr 11, s. 22-29.

Krzyżanowska Krystyna, 2014: Skuteczność działań informacyjno-promocyjnych w turystyce wiejskiej. ,Zeszyty Naukowe Uniwersytetu Szczecińskiego. Ekonomiczne Problemy Turystyki”, nr 3(27), s. 41-55.

Matlegiewicz Małgorzata, 2015: Agroturystyka - pozarolniczy biznes polskiej wsi. „Ekonomia i Środowisko", nr 4(55), s. 221-234.

Morbitzer Janusz, 2012: O istocie medialności młodego pokolenia. „Neodidagmata”, nr 33/34, s. 131-153.

Ochim Halina, Beata Pańczyk, 2016: RWD jako narzędzie optymalizacji stron internetowych. „Informatyka, Automatyka, Pomiary w Gospodarce i Ochronie Środowiska”, nr 4, s. 81-86. doi: 10.5604/01.3001.0009.5196.

Platania Marco, 2014: Agritourism Farms and the Web. An Exploratory Evaluation of their Websites. „Agris on-line Papers in Economics and Informatics”, no. 6(3), p. 51-58.

Plaza Beatriz, 2011: Google Analytics for measuring website performance. „Tourism Management”, no. 32(3), p. 477-481. doi: 10.1016/j.tourman.2010.03.015.

Płoszajski Piotr, 2013: Big Data: nowe źródlo przewag $i$ wzrostu firm. „E-mentor”, nr 3(50), s. 5-10.

Rek Damian, Piotr Sulikowski, 2011: Optymalizacja interfejsów sklepów internetowych a maksymalizacja sprzedaży. „Studia i Materiały Polskiego Stowarzyszenia Zarządzania Wiedzą”, nr 57, s. 214-224.

Roman Michał, 2013: Doradztwo w zakresie adaptacji domów i budynków gospodarczych na cele turystyki wiejskiej [w] Komunikowanie i doradztwo w turystyce wiejskiej, Krystyna Krzyżanowska (red.). Wydawnictwo SGGW, Warszawa, s. 178-188.

Sanders John, Laura Galloway, 2013: Rural small firms' website quality in transition and market economies. ,Journal of Small Business and Enterprise Development”, no. 20(4), p. 788-806. doi: 10.1108/JSBED-01-2012-0009. 
Sikora Jan, 2012: Agroturystyka. Przedsiębiorczość na obszarach wiejskich. C.H. Beck, Warszawa.

Sikorska-Wolak Izabella, Zawadka Jan, 2016: Innowacyjne rozwiazania w turystyce wiejskiej. „,Roczniki Naukowe Stowarzyszenia Ekonomistów Rolnictwa i Agrobiznesu”, nr 18(4), s. 207-212.

Singhal Amit, Matt Cutts, 2010: Using site speed in web search ranking. „Google Webmaster Central Blog", https://goo.gl/sVusvY, dostęp: 24.05.2017.

Sirko Mieczysław, Janusz Bek, 2006: Rola turystyki w rozwoju gospodarczym obszarów wiejskich i leśnych. Wydawnictwo WSE, Stalowa Wola.

Sroka Wojciech, Tomasz Wojewodzic, 2010: Agroturystyka - panaceum na problemy rolnictwa? „Problemy Zagospodarowania Ziem Górskich”, nr 57, s. 31-39.

Suchacka Grażyna, 2010: Modelowanie ruchu webowego dla potrzeb badania wydajności biznesowego serwisu $W W W$. „Pomiary Automatyka Robotyka”, nr 14, s. 57-60.

Śledzik Karol, 2014: Wykorzystanie unitaryzacji zerowanej do analizy porównawczej przewagi konkurencyjnej spótekz sektora ,,High-Tech ” $i$,, Medium High-Tech”, ,Zarządzanie i Finanse”, nr 3(2), s. 255-274.

Tyran Ewa, 2010: Dywersyfikacja jako proces dostosowawczy gospodarstw województwa małopolskiego. „Roczniki Nauk Rolniczych, seria G”, nr 97(4), s. 200-209.

Uglis Jarosław, Anna Jęczmyk, 2009: Agroturystyka szansa ożywienia obszarów wiejskich. „Roczniki Naukowe Stowarzyszenia Ekonomistów Rolnictwa i Agrobiznesu", nr 11(4), s. 341-346.

Walesiak Marek, 2014: Przeglad formuł normalizacji wartości zmiennych oraz ich własności w statystycznej analizie wielowymiarowej. „Przegląd Statystyczny”, nr 61(4), s. 363-372.

Wilk Iwona, Keck-Wilk Małgorzata, 2013: Oczekiwania turystów dotyczace oferty gospodarstw agroturystycznych. ,Journal of Agribusiness and Rural Development”, nr 2(28), s. 243-250.

Wojciechowska Jolanta, 2010: Agroturystyka - signum polskiej turystyki, „Acta Scientiarum Polonorum. Oeconomia", nr 9, s. 597-606.

Zatwarnicka Anna, Krzysztof Zatwarnicki, 2011: Pomiary wydajności popularnych serwerów webowych. „Studia Informatica”, nr 32(3A), s. 103-112.

Zawadka Jan, 2014: Społeczno-ekonomiczne uwarunkowania rozwoju działalności agroturystycznej, „Turystyka i Rozwój Regionalny”, nr 1, s. 133-141.

Zhu Yuhao, Vijay Janapa Reddi, 2013: High-performance and energy - efficient mobile web browsing on big/little systems. „In High Performance Computer Architecture (HPCA2013), IEEE 19th International Symposium on", p. 13-24.

Zopounidis Constantin, Christos Lemonakis, Zacharoula Andreopoulou, Christiana Koliouska, 2014: Agrotourism Industry Development through Internet Technologies: A Multicriteria Approach. „Journal of Euromarketing", no. 23(4), p. 45-67. doi: 10.9768/0023.04.045.

\title{
Karol Król \\ EFFICIENCY OF WEBSITES OF AGROTOURISTIC FARMS
}

\begin{abstract}
Summary
Dynamics of agrotourism development depends to a large extent on marketing activities, including promotion of services. Numerous owners of agrotouristic farms use websites to present their offers and approach a wider range of customers. Such attributes of a website like: usability, functionality, interactivity and efficiency are often regarded as a promise of a high quality offer which is considered by a customer to be used. The aim of the paper was to measure efficiency of websites of agrotouristic farms. The surveys were of pilot character and were performed in the set of 100 websites the addresses of which were obtained by means of Google search engine as well as one of nationwide catalogues. The efficiency tests were conducted by means of selected internet applications. Moreover, selected extreme cases were examined in detail. It was proved in the conclusion that the websites of agrotouristic farms are characterized by the satisfactory level of efficiency which, however, does not always correspond with their effectivity and performance quality.
\end{abstract}

Adres do korespondencji: Dr inż. Karol Król

Uniwersytet Rolniczy w Krakowie Katedra Gospodarki Przestrzennej i Architektury Krajobrazu, Wydział Inżynierii Środowiska i Geodezji ul. Mickiewicza 24/28, 30-059 Kraków e-mail:k.krol@onet.com.pl 